Article

\title{
Regulation of Oncogenic Targets by miR-99a-3p (Passenger Strand of miR-99a-Duplex) in Head and Neck Squamous Cell Carcinoma
}

\author{
Reona Okada ${ }^{1,+}$, Keiichi Koshizuka ${ }^{1,2, \dagger}$, Yasutaka Yamada ${ }^{1}$, , Shogo Moriya ${ }^{3}$, \\ Naoko Kikkawa ${ }^{1,2}$, Takashi Kinoshita ${ }^{2}$, Toyoyuki Hanazawa ${ }^{2}$ and Naohiko Seki ${ }^{1, *(D)}$ \\ 1 Department of Functional Genomics, Chiba University Graduate School of Medicine, Chiba 260-8670, Japan; \\ reonaokada@chiba-u.jp (R.O.); kkoshizuka@chiba-u.jp (K.K.); yasutaka1205@olive.plala.or.jp (Y.Y.); \\ naoko-k@hospital.chiba-u.jp (N.K.) \\ 2 Department of Otorhinolaryngology/Head and Neck Surgery, Chiba University Graduate School of \\ Medicine, Chiba 260-8670, Japan; t.kinoshita903@gmail.com (T.K.); thanazawa@faculty.chiba-u.jp (T.H.) \\ 3 Department of Biochemistry and Genetics, Chiba University Graduate School of Medicine, Chiba 260-8670, \\ Japan; moriya.shogo@chiba-u.jp \\ * Correspondence: naoseki@faculty.chiba-u.jp; Tel.: +81-43-226-2971; Fax: +81-43-227-3442 \\ + These authors contributed equally to this work.
}

Received: 3 November 2019; Accepted: 27 November 2019; Published: 28 November 2019

\begin{abstract}
To identify novel oncogenic targets in head and neck squamous cell carcinoma (HNSCC), we have analyzed antitumor microRNAs (miRNAs) and their controlled molecular networks in HNSCC cells. Based on our miRNA signature in HNSCC, both strands of the miR-99a-duplex (miR-99a-5p: the guide strand, and miR-99a-3p: the passenger strand) are downregulated in cancer tissues. Moreover, low expression of miR-99a-5p and miR-99a-3p significantly predicts poor prognosis in HNSCC, and these miRNAs regulate cancer cell migration and invasion. We previously showed that passenger strands of miRNAs have antitumor functions. Here, we screened miR-99a-3p-controlled oncogenes involved in HNSCC pathogenesis. Thirty-two genes were identified as miR-99a-3p-regulated genes, and 10 genes (STAMBP, TIMP4, TMEM14C, CANX, SUV420H1, HSP90B1, PDIA3, MTHFD2, BCAT1, and SLC22A15) significantly predicted 5-year overall survival. Notably, among these genes, STAMBP, TIMP4, TMEM14C, CANX, and SUV42OH1 were independent prognostic markers of HNSCC by multivariate analyses. We further investigated the oncogenic function of STAMBP in HNSCC cells using knockdown assays. Our data demonstrated that the aggressiveness of phenotypes in HNSCC cells was attenuated by siSTAMBP transfection. Moreover, aberrant STAMBP expression was detected in HNSCC clinical specimens by immunohistochemistry. This strategy may contribute to the clarification of the molecular pathogenesis of this disease.
\end{abstract}

Keywords: head and neck squamous cell carcinoma; microRNA; miR-99a-3p; passenger strand; antitumor; STAMBP

\section{Introduction}

Head and neck squamous cell carcinoma (HNSCC) is the sixth most common cancer, with approximately 650,000 new cases diagnosed annually and 400,000 HNSCC-related deaths worldwide each year [1]. Tobacco and alcohol drinking habits are the major risk factors of HNSCC carcinogenesis [2]. In the past decade, our understanding of the role of human papillomavirus in the development of oropharyngeal squamous cell carcinoma has significantly changed the treatment strategy of this disease [3,4]. HNSCC is typically diagnosed when already at an advanced stage. Despite advancements in surgery, radiation therapy, and chemotherapy, patients with advanced HNSCC have a poor 
prognosis [1,4] owing to recurrence, metastasis, and treatment resistance [5]. The median overall survival time for patients with recurrence and metastasis is 10-13 months in the setting of first-line chemotherapy and 6 months in the second-line setting [6]. Recently, epidermal growth factor receptor inhibitors and immune checkpoint inhibitors have emerged as therapeutic approaches in HNSCC treatment $[7,8]$. However, these treatments do not yield satisfactory results.

MicroRNAs (miRNAs) exist widely in eukaryotes, and more than 2500 types of mature miRNAs have been discovered in humans $[9,10]$. miRNAs are transcribed from the human genome and then processed into mature miRNAs of approximately $18-22$ bases $[9,10]$. miRNAs are classified as noncoding RNAs and function to suppress the translation of mRNAs by binding to the complementary sequence in the $3^{\prime}$-untranslated region ( $3^{\prime}$-UTR) of the targeted mRNA $[9,10]$. Notably, one miRNA targets multiple mRNAs, and there are multiple miRNA binding sites in the UTRs of one mRNA $[9,10]$. Therefore, changes in the expression of miRNAs are involved in various diseases, including human cancers, suggesting that miRNAs play important roles in disease development [11-15].

We have been studying antitumor miRNAs and their oncogenic networks in HNSCC cells based on HNSCC miRNA signatures [16-20]. Our previous studies have shown that the antitumor miR-29 family directly controls laminin-332 and integrins (ITGA6, ITGB4, and ITGB1), and miR-199 family targets ITGA3 in HNSCC cells [21-23]. Moreover, the antitumor miR-26 family, miR-29 family, and miR-218 inhibit cancer cell migration and invasion in HNSCC cells, and these miRNAs coordinately regulate lysyl oxidase like 2 [24]. These antitumor miRNAs (the $m i R-26$ family, the $m i R-29$ family, $m i R-218$, and the miR-199 family) target proteins involved in the epithelial-mesenchymal transition, indicating their pivotal roles in metastasis in cancer cells.

In this study, we focused on miR-99a-5p (the guide strand of the miR-99a-duplex) and miR-99a-3p (the passenger strand) based on our HNSCC miRNA signature determined by RNA sequencing [20]. Previous studies have shown that downregulation of miR-99a-5p occurs in various cancers and that the expression of this miRNA attenuates malignant phenotypes in cancer cells, suggesting that miR-99a-5p acts as an antitumor miRNA $[25,26]$. However, few reports have described the roles of the passenger strand $m i R-99 a-3 p$ in HNSCC, and oncogenic networks controlled by miR-99a-3p are still unknown. In the general concept of miRNA biogenesis, passenger strands of miRNAs are degraded in the cytosol and have no function $[9,10]$. However, our previous studies showed that some passenger strands of miRNAs, e.g., miR-145-3p, miR-150-3p, and miR-199a/b-3p were downregulated in the signature and acted as antitumor miRNAs in malignant cells. Importantly, several targets regulated by these passenger strands of miRNAs acted as oncogenes, and their aberrant expressions were closely associated with the poor prognosis of the patients [23,27-30]. Therefore, the analysis of passenger strands of miRNAs is useful for understanding the molecular pathogenesis of HNSCC.

Our functional assays indicated that ectopic expression of both strands of the miR-99a-duplex significantly attenuated malignant phenotypes in HNSCC cells. We further analyzed miR-99a-3p-regulated oncogenic genes involved in HNSCC molecular pathogenesis. In total, 32 genes were identified as miR-99a-3p-controlled genes, and 10 genes (STAMBP, TIMP4, TMEM14C, CANX, SUV420H1, HSP90B1, PDIA3, MTHFD2, BCAT1, and SLC22A15) significantly predicted 5-year overall survival in patients with HNSCC. Moreover, our findings revealed that aberrant expression of STAMBP enhanced cancer cell aggressiveness in HNSCC.

\section{Materials and Methods}

\subsection{Clinical Human HNSCC Specimens and HNSCC Cell Lines}

Twenty-two clinical specimens were obtained from patients with HNSCC following surgical tumor resection at Chiba University Hospital (2008-2013, Chiba, Japan). The patients' clinical characteristics are shown in Table 1. Written informed consent was obtained from all patients before the use of their specimens. This study was approved by the Bioethics Committee of Chiba University (approval number: 811(690)). Normal tissue was collected from the most distant cancerous part of the same 
specimen. A total of 22 pairs of HNSCC tissues and adjacent normal (noncancerous) tissues were obtained in this study.

Table 1. Clinical features of 22 HNSCC patients.

\begin{tabular}{ccccccccc}
\hline No. & Age & Sex & Location & T & N & M & Stage & Differentiation \\
\hline 1 & 66 & M & hypopharynx & 2 & $2 \mathrm{c}$ & 0 & IVa & moderate \\
2 & 66 & M & hypopharynx & $4 \mathrm{a}$ & $2 \mathrm{c}$ & 0 & IVa & well \\
3 & 66 & $\mathrm{M}$ & hypopharynx & $4 \mathrm{~b}$ & $2 \mathrm{c}$ & 0 & IVb & moderate \\
4 & 76 & $\mathrm{M}$ & hypopharynx & $4 \mathrm{a}$ & 1 & 0 & IVa & well \\
5 & 74 & $\mathrm{M}$ & hypopharynx & $4 \mathrm{a}$ & $2 \mathrm{c}$ & 0 & IVa & poor \\
6 & 45 & $\mathrm{M}$ & hypopharynx & $4 \mathrm{a}$ & $2 \mathrm{c}$ & 0 & IVa & moderate \\
7 & 75 & $\mathrm{M}$ & hypopharynx & $4 \mathrm{a}$ & $2 \mathrm{c}$ & 0 & IVa & well \\
8 & 58 & $\mathrm{M}$ & hypopharynx & $4 \mathrm{a}$ & 0 & 0 & IVa & well \\
9 & 69 & $\mathrm{M}$ & larynx & 3 & 0 & 0 & III & well \\
10 & 70 & $\mathrm{M}$ & larynx & $4 \mathrm{a}$ & 1 & 0 & IVa & well-moderate \\
11 & 84 & $\mathrm{M}$ & larynx & $4 \mathrm{a}$ & 0 & 0 & IVa & moderate \\
12 & 50 & $\mathrm{M}$ & larynx & $4 \mathrm{a}$ & $2 \mathrm{~b}$ & 0 & IVa & moderate \\
13 & 82 & $\mathrm{M}$ & larynx & $4 \mathrm{a}$ & 0 & 0 & IVa & moderate \\
14 & 85 & $\mathrm{M}$ & larynx & 3 & $2 \mathrm{~b}$ & 0 & IVa & moderate \\
15 & 66 & $\mathrm{M}$ & tongue & 2 & 0 & 0 & II & moderate \\
16 & 73 & $\mathrm{M}$ & tongue & 3 & 1 & 0 & III & poor \\
17 & 74 & $\mathrm{M}$ & tongue & 1 & 0 & 0 & I & well \\
18 & 72 & $\mathrm{M}$ & tongue & $4 \mathrm{a}$ & $2 \mathrm{~b}$ & 0 & IVa & moderate \\
19 & 83 & $\mathrm{M}$ & oral floor & 2 & 1 & 0 & III & well \\
20 & 68 & $\mathrm{~F}$ & oral floor & $4 \mathrm{a}$ & 1 & 0 & IVa & well \\
21 & 77 & $\mathrm{M}$ & oral floor & 2 & $2 \mathrm{~b}$ & 0 & IVa & moderate \\
22 & 69 & $\mathrm{M}$ & oropharynx & 1 & 0 & 0 & I & well \\
\hline
\end{tabular}

T: Primary tumor stage, N: Regional lymph nodes stage, M: Distant metastasis stage. All according to the UICC (The Union for International Cancer Control) classification.

Two HNSCC cell lines, FaDu (American Type Culture Collection, Manassas, VA, UAS) and SAS cells (RIKEN Cell Bank, Tsukuba, Ibaraki, Japan), were used in this study.

\subsection{RNA Extraction and Quantitative Real-Time Reverse Transcription Polymerase Chain Reaction (qRT-PCR)}

RNA was extracted from clinical specimens and cell lines as previously described [20,23,30-32]. miRNA expression levels were evaluated using qRT-PCR as described previously [20,23,30-32]. The TaqMan probes and primers used in this study are listed in Table S2.

\subsection{Transfection of miRNAs, siRNAs, and Plasmid Vectors into HNSCC Cells}

The procedures for transfection of miRNAs, siRNAs, and plasmid vectors into HNSCC cells were described previously $[20,23,30-32]$. The reagents used in this study are listed in Table S2.

\subsection{Functional Assays in HNSCC Cells (Cell Proliferation, Migration and Invasion Assays)}

The procedures for functional assays in cancer cells (proliferation, migration, and invasion) are described in our previous studies [20,23,30-32]. Cells were transfected with 10nM miRNAs or siRNAs. Cell proliferation was evaluated with XTT assays. Migration assays were performed with uncoated transwell polycarbonate membrane filters, invasion assays with modified Boyden chambers.

\subsection{Measurement of miR-99a-3p Incorporated into the RISC}

Immunoprecipitation using anti-Ago2 antibodies was performed to determine whether miR-99a-3p was incorporated into the RISC. FaDu and SAS were transfected with 10nM miRNAs for $48 \mathrm{~h}$ and the collected cells went through immunoprecipitation using human anti-Ago2 antibodies (microRNA Isolation Kit, Human Ago2; Wako, Osaka, Japan) according to the manufacture's 
protocol. Obtained miRNAs proceeded to qRT-PCR. For normalization of the results, miR-26a was measured, whose expression was not affected by miR-99a-5p/3p transfection. The procedure for immunoprecipitation was described in previous studies [23,30-32]. The reagents used in this study are listed in Table S2.

\subsection{Identification of miR-99a-3p and miR-99a-5p Targets in HNSCC Cells}

The strategy for identification of miRNA targets in this study is summarized in Figure S5. Two expression profiles (i.e., miR-99a-5p-transfected FaDu cells [GEO accession number: GSE123318], miR-99a-3p-transfected FaDu cells [accession number: GSE123318]) were used in this screening. The TargetScanHuman database (http://www.targetscan.org/vert_72/) was used to predict miRNA binding sites.

\subsection{Plasmid Construction and Dual-Luciferase Reporter Assays}

Plasmid vectors, including vectors containing the wild-type sequences of $m i R-99 a-3 p$ binding sites in the $3^{\prime}$-UTR of STAMBP or the deletion sequences of miR-99a-3p binding sites in the $3^{\prime}$-UTR of $S T A M B P$, were prepared. The inserted sequences are shown in Figure S7. The procedures for transfection and dual luciferase reporter assays were described in our previous studies [20,23,30-32]. The reagents used in this study are listed in Table S2.

\subsection{Clinical Data Analyses of miRNAs and Target Genes in HNSCC Specimens}

TCGA (https://tcga-data.nci.nih.gov/tcga/) was applied to investigate the clinical significance of miRNAs and their target genes. Gene expression and clinical data were obtained from cBioPortal (http: //www.cbioportal.org/) and OncoLnc (http://www.oncolnc.org/) (data downloaded on 1 August 2019).

\subsection{Western Blotting and Immunohistochemistry}

The procedures for Western blotting and immunohistochemistry were described in our previous studies [20,23,30-32]. The antibodies used in this study are listed in Table S2.

\subsection{Statistical Analyses}

Mann-Whitney U tests were applied for comparisons between two groups. For multiple groups, one-way analysis of variance and Tukey tests for post-hoc analysis were applied. These analyses were performed with JMP Pro 14 (SAS Institute Inc., Cary, NC, USA).

\section{Results}

\subsection{Downregulation and Clinical Significance of miR-99a-5p and miR-99a-3p in HNSCC Clinical Specimens}

The clinical features of HNSCC specimens are listed in Table 1. Expression levels of miR-99a-5p and $m i R-99 a-3 p$ were significantly low in cancer tissues compared with those in normal tissues from the same patients ( $p<0.0001$ and $p<0.0001$, respectively; Figure 1A and Figure S1). The expression levels of these miRNAs in two HNSCC cell lines (FaDu and SAS cells) were also very low compared with those in normal tissues (Figure 1A and Figure S1). A positive correlation was detected between $m i R-99 a-5 p$ and $m i R-99 a-3 p$ expression levels by Spearman's rank analysis $(\mathrm{R}=0.716, p<0.0001$; Figure 1B).

Cohort analysis using data from The Cancer Genome Atlas (TCGA) database revealed that low expression of $m i R-99 a-5 p$ and $m i R-99 a-3 p$ was associated with poorer survival in patients with HNSCC $(p=0.0008$ and $p=0.0012$, respectively; Figure 1C). We confirmed positive correlation of these miRNAs expression by using TCGA database sets (Figure S2). 
A

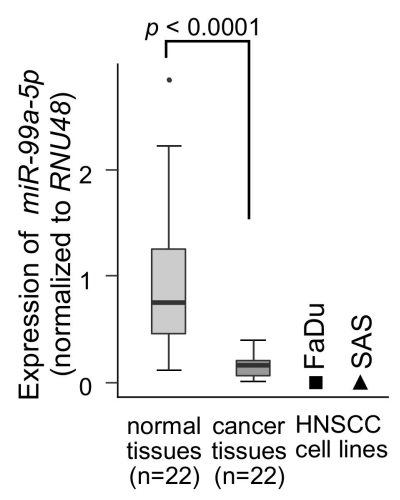

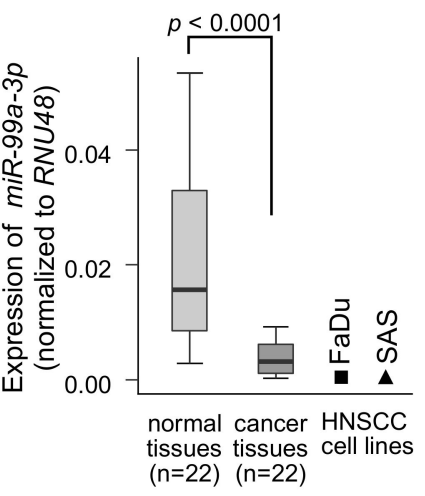

B

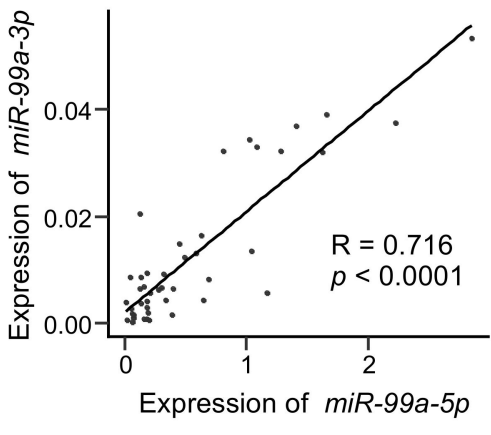

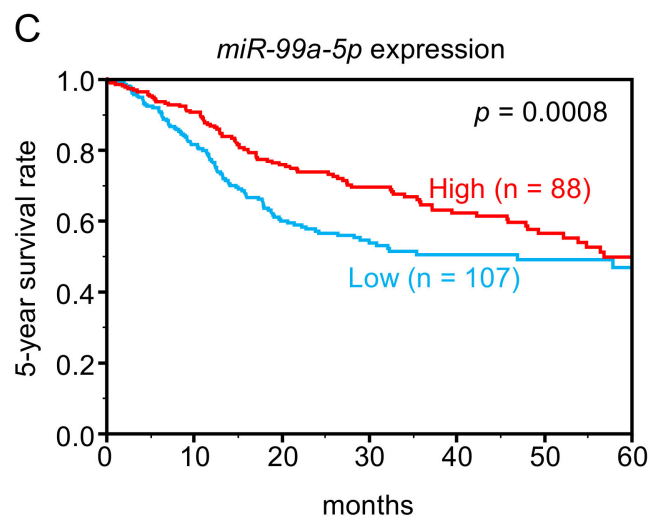

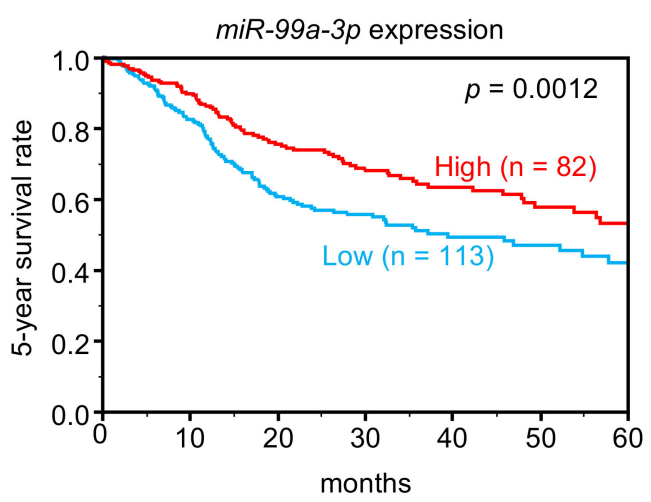

Figure 1. Expression and clinical significance of $m i R-99 a-5 p$ and $m i R-99 a-3 p$ in HNSCC clinical specimens. (A) Expression of $m i R-99 a-5 p$ and $m i R-99 a-3 p$ was significantly reduced in HNSCC clinical specimens and cell lines (FaDu and SAS cells). Data were normalized to the expression of RNU48. (B) Spearman's rank tests showed positive correlations between expression levels of miR-99a-5p and miR-99a-3p in clinical specimens. (C) Kaplan-Meier survival curve analyses of patients with HNSCC using data from The Cancer Genome Atlas (TCGA) database. Patients were divided into two groups according to miRNA expression, high group and low group (according to median expression). The red line shows the high expression group, and the blue line shows the low expression group.

3.2. Ectopic Expression of miR-99a-5p and miR-99a-3p on Cell Proliferation, Migration and Invasion in HNSCC Cells

To investigate the anti-tumor functions of $m i R-99 a-5 p$ and $m i R-99 a-3 p$ in HNSCC cells, we assessed changes in cell proliferation, migration, and invasion after transfection of these miRNAs into FaDu and SAS cells. Notably, ectopic expression of miR-99a-5p significantly decreased cell proliferation (Figure 2A). However, cell proliferation was not affected by miR-99a-3p transfection. Additionally, the migration and invasion of FaDu and SAS cells were significantly suppressed by $m i R-99 a-5 p$ and miR-99a-3p transfection (Figure 2B,C). Photomicrographs are presented in Figure S3. 



Figure 2. Functional assays of cell proliferation, migration, and invasion following ectopic expression of $m i R-99 a-5 p$ and $m i R-99 a-3 p$ in HNSCC cell lines (FaDu and SAS cells). (A) Cell proliferation was assessed using XTT assays. Data were collected $72 \mathrm{~h}$ after miRNA transfection $\left({ }^{*} p<0.0001\right)$. (B) Cell migration was assessed with membrane culture system. Data were collected $48 \mathrm{~h}$ after seeding the cells into the chambers $\left({ }^{*} p<0.0001\right)$. (C) Cell invasion was determined $48 \mathrm{~h}$ after seeding miRNA-transfected cells into chambers using Matrigel invasion assays $(* p<0.0001)$.

3.3. Incorporation of miR-99a-5p and miR-99a-3p into the RNA-Induced Silencing Complex (RISC) in HNSCC Cells

Ago2 is an essential component of the RISC. Therefore, to verify that miR-99a-5p and miR-99a-3p had functions in HNSCC cells, immunoprecipitation assays were carried out using anti-Ago2 antibodies. After transfection of both miRNAs to SAS cells, the amounts of miR-99a-5p and miR-99a-3p were significantly increased relative to that in control (untransfected) cells (Figure S4). These data showed that $m i R-99 a-5 p$ (the guide strand) and miR-99a-3p (the passenger strand) were both incorporated into the RISC in HNSCC cells.

\subsection{Screening of Molecular Targets Regulated by miR-99a-5p and miR-99a-3p in HNSCC Cells}

To identify the genes controlled by miR-99a-5p and miR-99a-3p in HNSCC cells, we used gene expression data obtained by RNA microarray analysis of miR-99a-5p-or miR-99a-3p-transfected FaDu cells and data from the TargetScanHuman database (release 7.2), which provided annotated putative targets for each miRNA. Our strategy searching for miR-99a-5p and miR-99a-3p target genes is shown in Figure S5.

Using this strategy, only genes from miR-99a-3p-transfected FaDu cells endured the selection process. For $m i R-99 a-3 p, 114$ genes were identified as putative target genes in HNSCC cells (Table 2). Eighteen genes were identified as $m i R-99 a-5 p$-controlled genes, none of which showed correlations with prognosis in TCGA database (Table S1). 
Table 2. Candidate target genes regulated by miR-99a-3p.




Table 2. Cont.

\begin{tabular}{|c|c|c|c|c|c|}
\hline $\begin{array}{l}\text { Entrez } \\
\text { Gene } \\
\text { ID }\end{array}$ & Gene Symbol & Gene Name & $\begin{array}{l}\text { Total } \\
\text { Sites }\end{array}$ & $\begin{array}{c}\text { FaDu } \\
m i R-99 a-3 p \\
\text { Transfectant } \\
\text { FC (log2) }\end{array}$ & $\begin{array}{c}\text { TCGA } \\
\text { OncoLnc } \\
\text { 5-Year OS } \\
p \text {-Value }\end{array}$ \\
\hline 100534599 & ISY1-RAB43 & ISY1-RAB43 readthrough & 1 & -2.4556 & 0.6928 \\
\hline 54431 & DNAJC10 & DnaJ (Hsp40) homolog, subfamily C, member 10 & 2 & -1.6506 & 0.7051 \\
\hline 63874 & ABHD4 & abhydrolase domain containing 4 & 1 & -1.6850 & 0.7071 \\
\hline 10961 & ERP29 & endoplasmic reticulum protein 29 & 1 & -1.0578 & 0.7355 \\
\hline 126626 & GABPB2 & GA binding protein transcription factor, beta subunit 2 & 2 & -1.1151 & 0.7488 \\
\hline 79794 & C12orf 49 & chromosome 12 open reading frame 49 & 1 & -1.7522 & 0.7864 \\
\hline 5965 & $R E C Q L$ & RecQ helicase-like & 3 & -1.2203 & 0.7885 \\
\hline 64651 & CSRNP1 & cysteine-serine-rich nuclear protein 1 & 1 & -2.1079 & 0.8036 \\
\hline 81558 & FAM117A & family with sequence similarity 117 , member $\mathrm{A}$ & 1 & -2.0458 & 0.8054 \\
\hline 7706 & TRIM25 & tripartite motif containing 25 & 2 & -1.2522 & 0.8360 \\
\hline 9497 & $S L C 4 A 7$ & solute carrier family 4 , sodium bicarbonate cotransporter, member 7 & 1 & -1.1702 & 0.9121 \\
\hline 54832 & VPS13C & vacuolar protein sorting 13 homolog C (S. cerevisiae) & 2 & -1.1051 & 0.9176 \\
\hline 23433 & RHOQ & ras homolog family member $\mathrm{Q}$ & 1 & -1.6436 & 0.9319 \\
\hline 55727 & BTBD7 & BTB (POZ) domain containing 7 & 1 & -1.2974 & 0.9480 \\
\hline 11260 & XРOT & exportin, tRNA & 1 & -1.4398 & 0.9544 \\
\hline 1362 & $C P D$ & carboxypeptidase D & 2 & -1.3036 & 0.9645 \\
\hline 151887 & CCDC80 & coiled-coil domain containing 80 & 2 & -2.1921 & 0.9667 \\
\hline 116496 & FAM129A & family with sequence similarity 129 , member A & 1 & -1.8099 & 0.9903 \\
\hline 9709 & HERPUD1 & $\begin{array}{l}\text { homocysteine-inducible, endoplasmic reticulum stress-inducible, } \\
\text { ubiquitin-like domain member } 1\end{array}$ & 1 & -3.3737 & $0.0854^{*}$ \\
\hline 284723 & SLC25A34 & solute carrier family 25 , member 34 & 1 & -1.5051 & $0.0757^{*}$ \\
\hline 83641 & FAM107B & family with sequence similarity 107 , member B & 1 & -2.2173 & $0.0749^{*}$ \\
\hline 60412 & EXOC4 & exocyst complex component 4 & 1 & -1.0957 & $0.0691^{*}$ \\
\hline 643707 & GOLGA6L4 & golgin A6 family-like 4 & 2 & -1.3773 & N/A \\
\hline
\end{tabular}

\subsection{Clinical Significance of miR-99a-3p Targets in HNSCC Pathogenesis}

By using TCGA database, we narrowed down the list of 114 genes according to correlations with 5-year overall survival rates. Among the genes, high expression of 10 genes (STAMBP, TIMP4, TMEM14C, CANX, SUV420H1, HSP90B1, PDIA3, MTHFD2, BCAT1, and SLC22A15) was associated with poor prognosis (5-year overall survival rate: $p<0.05$ ) in patients with HNSCC (Table 2 and Figure 3). Furthermore, multivariate analysis elucidated that expression levels of five genes (STAMBP, TIMP4, TMEM14C, SUV420H1, and CANX) were independent prognostic factors for 5-year overall survival in these patients (Figure 4).

\subsection{Direct Regulation of STAMBP by miR-99a-3p in HNSCC Cells}

In cells transfected with miR-99a-3p, the levels of STAMBP mRNA and STAMBP protein were significantly lower than in mock- or miR-control-transfected cells (Figure 5A,B). The whole pictures of Western blotting are shown in Figure S6. In addition, we investigated whether the other four genes (TIMP4, TMEM14C, SUV420H1, and CANX) were controlled by miR-99a-3p in HNSCC cells at the RNA levels. Consistent with the estimation of TargetScanHuman database, the expression levels of the four genes were also downregulated by miR-99a-3p transfection in HNSCC cells (Figure S8).

Next, we performed dual-luciferase reporter assays to determine whether $S T A M B P$ was directly regulated by miR-99a-3p. We used vectors encoding the partial wild-type sequences of the $3^{\prime}$-UTR of $S T A M B P$, including the predicted $m i R-99 a-3 p$ target site deletion vector lacking the $m i R-99 a-3 p$ 
binding site (Figure 5C and Figure S7). We found that luciferase activity was significantly decreased by cotransfection with miR-99a-3p and the vector carrying the wild-type $3^{\prime}$-UTR of STAMBP, whereas transfection with the deletion vector blocked the decrease in luminescence in FaDu and SAS cells (Figure 5D). These data demonstrated that miR-99a-3p directly bound to the $3^{\prime}$-UTR of STAMBP.
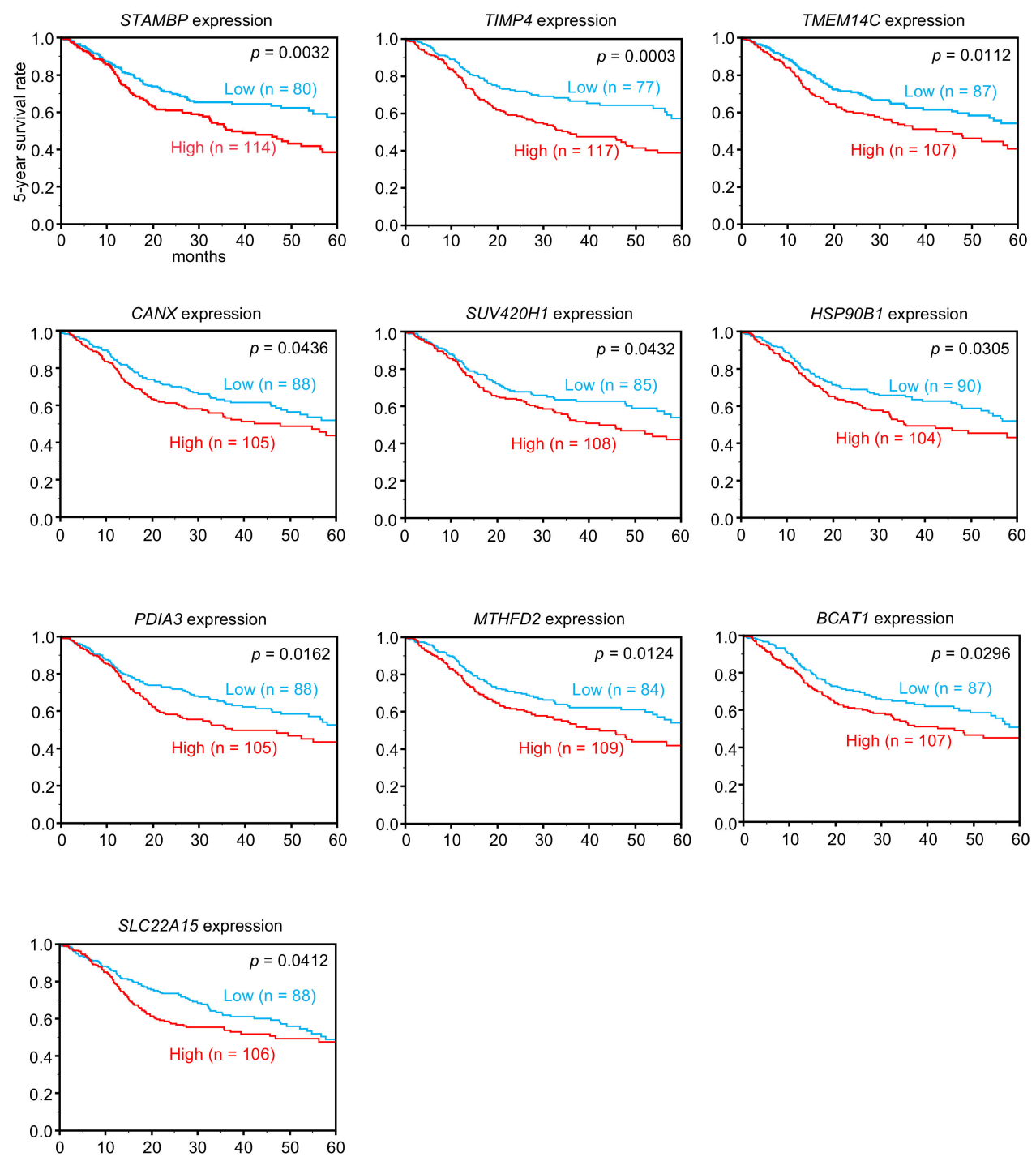

Figure 3. Clinical significance of $m i R-99 a-3 p$ target genes in TCGA database. Among putative targets of miR-99a-3p in HNSCC cells, high expression of 10 genes (STAMBP, TIMP4, TMEM14C, CANX, SUV420H1, HSP90B1, PDIA3, MTHFD2, BCAT1, and SLC22A15) was significantly associated with poor prognosis in patients with HNSCC. Kaplan-Meier curves of 5-year overall survival for each gene are shown. 

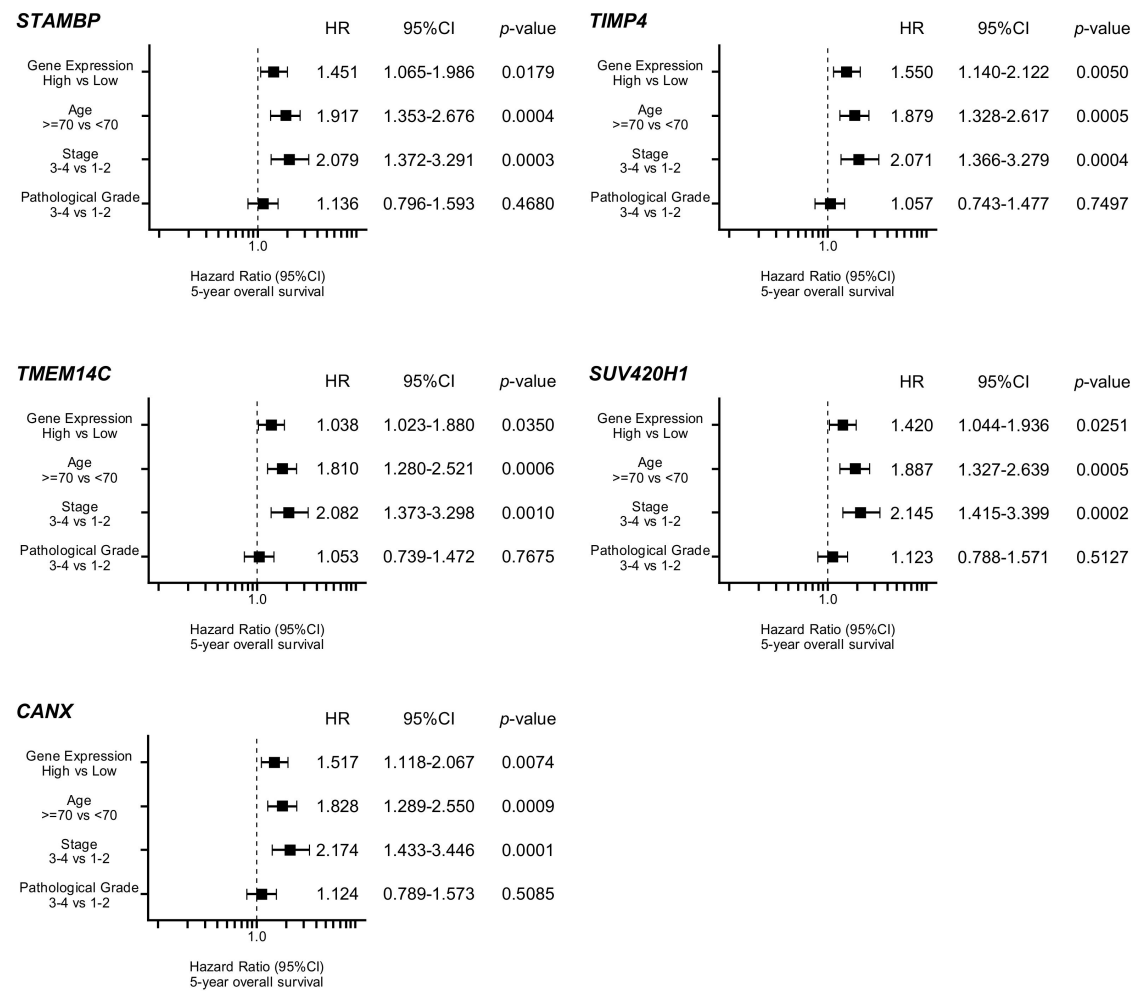

Figure 4. Forest plot of multivariate analysis of five genes (STAMBP, TIMP4, TMEM14C, SUV420H1, and $C A N X)$, which were independent prognostic factors for overall survival after adjustment for patient age, disease, stage, and pathological grade.

A

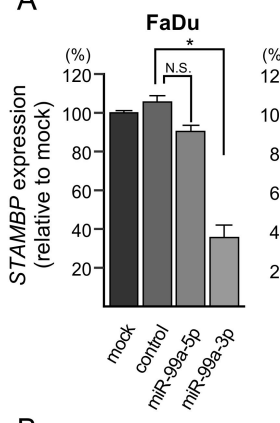

B

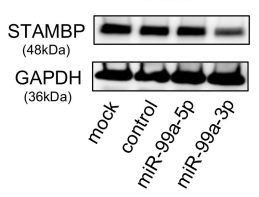

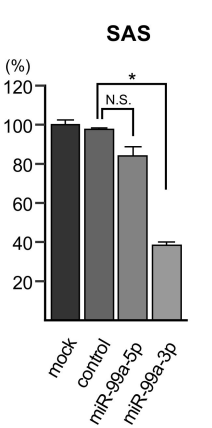

SAS

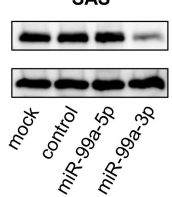

C

miR-99a-3p binding site: position 477-483 of STAMBP 3'UTR

Wild-type $\quad 5$ '....AugGCAAUAUGAaUgGagcUUAu.... 3'

miR-99a-3p $\|_{\text {GUCUGGGAUCUUCG-CUCGAAC }}$

Deletion-type 5' ...AUGGCA--------_----_... 3'

D


(\%)
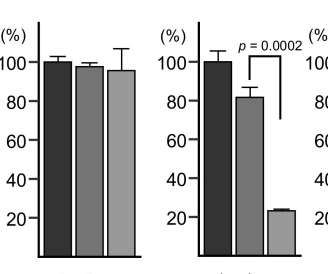

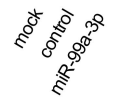



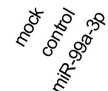

Figure 5. Expression of $S T A M B P / S T A M B P$ was directly regulated by miR-99a-3p in HNSCC cells. (A) Expression of STAMBP mRNA was significantly reduced by miR-99a-3p transfection into FaDu and SAS cells $\left(72 \mathrm{~h}\right.$ after transfection; ${ }^{*} p<0.0001$, N.S.: Not significant). Expression of GAPDH was used as an internal control. (B) Expression of STAMBP protein was reduced by miR-99a-3p transfection into HNSCC cells (72 h after transfection). Expression of GAPDH was used as an internal control. (C) TargetScanHuman database analyses predicted one putative $m i R-99 a-3 p$ binding site in the $3^{\prime}$-UTR of STAMBP. (D) Dual luciferase reporter assays showed that luminescence activities were reduced by cotransfection with wild-type (miR-99a-3p binding site) vectors and miR-99a-3p in FaDu and SAS cells. Normalized data were calculated as Renilla/firefly luciferase activity ratios (N.S.: Not significant). 


\subsection{Effects of STAMBP Knockdown on Cell Proliferation, Migration, and Invasion in HNSCC Cells}

To investigate the oncogenic functions of STAMBP in HNSCC cells, knockdown assays were conducted using small interfering RNAs (siRNAs). Both mRNA and protein expression levels were successfully suppressed by siSTAMBP-1 and siSTAMBP-2 transfection into FaDu and SAS cells (Figure 6A,B). The whole pictures of Western blotting are shown in Figure S6.

A

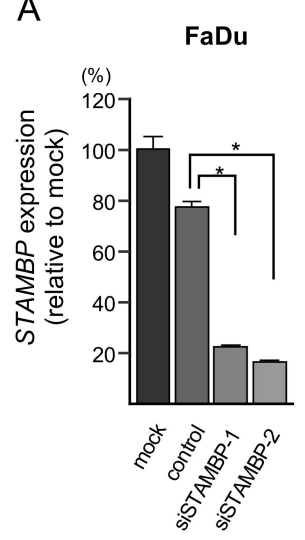

B

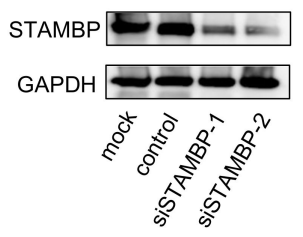

D

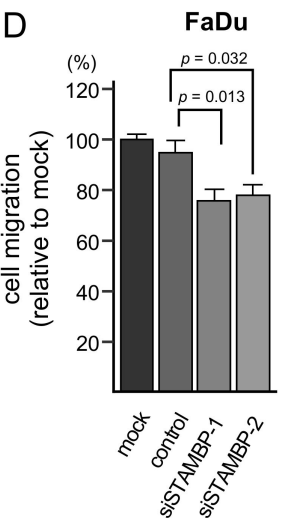



C
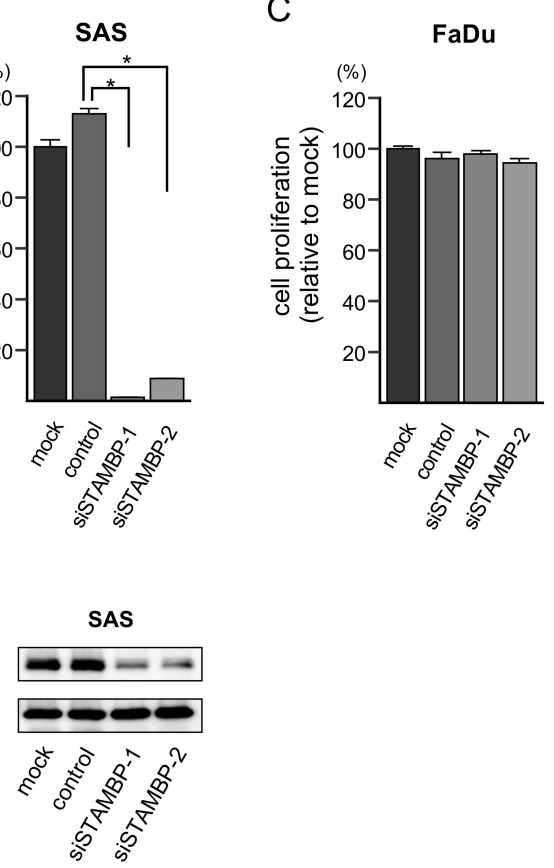

SAS



E

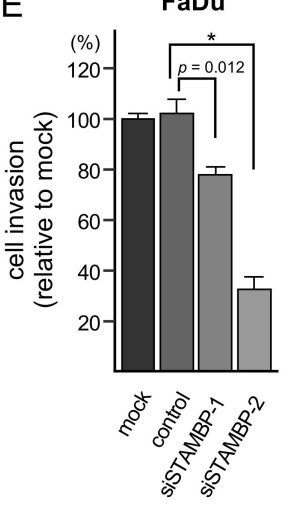

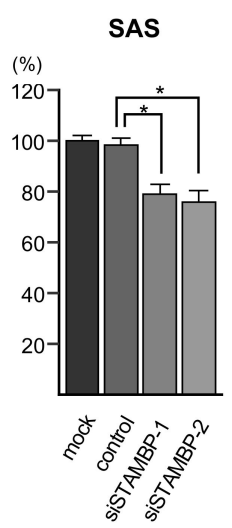

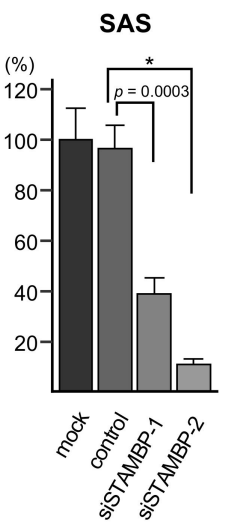

Figure 6. Effects of $S T A M B P$ knockdown on cell proliferation, migration, and invasion in HNSCC cells. (A) Expression of STAMBP mRNA was significantly reduced by siRNA transfection into HNSCC cells $\left({ }^{*} p<0.0001\right)$. Expression of GAPDH was used as an internal control. (B) Expression of STAMBP protein was markedly reduced by siRNA transfection into HNSCC cells. Expression of GAPDH was used as an internal control. (C) Cell proliferation was assessed using XTT assays. Data were collected $72 \mathrm{~h}$ after miRNA transfection ( $\left.{ }^{*} p<0.0001\right)$. (D) Cell migration was assessed with a membrane culture system. Data were collected $48 \mathrm{~h}$ after seeding the cells into the chambers $\left({ }^{*} p<0.0001\right)$. (E) Cell invasion was determined $48 \mathrm{~h}$ after seeding miRNA-transfected cells into chambers using Matrigel invasion assays $\left({ }^{*} p<0.0001\right)$.

In functional assays, cell proliferation was not suppressed by siSTAMBP transfection into FaDu cells. Besides, in SAS cells, cell proliferation was significantly suppressed by siSTAMBP transfection 
(Figure 6C). Cell migration and invasive abilities were significantly blocked by knockdown of STAMBP (siSTAMBP-1 and siSTAMBP-2) in FaDu and SAS cells (Figure 6D,E). The photomicrographs are shown in Figure S3. Regarding the cell proliferation assay, the results differed between FaDu cells and SAS cells. To explain this phenomenon, a detailed analysis of genes involved in cell cycle and cell division for two cell lines will be necessary.

\subsection{Overexpression of STAMBP in HNSCC Clinical Specimens}

Expression of STAMBP protein was evaluated using HNSCC clinical specimens. Overexpression of STAMBP was detected in cancer lesions in HNSCC clinical specimens (Figure 7A-H). In contrast to cancer lesions, expression of STAMBP was extremely weak in normal mucosa (Figure 7J). Information on clinical specimens used for immunostaining is shown in Table 3.

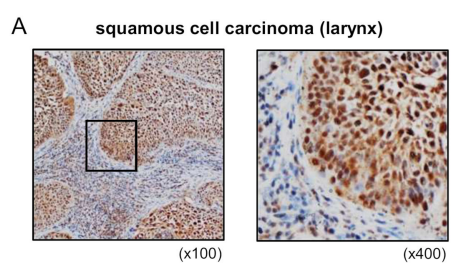

C

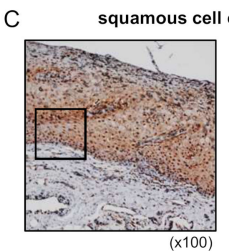

$\mathrm{E}$

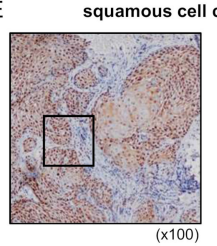

G
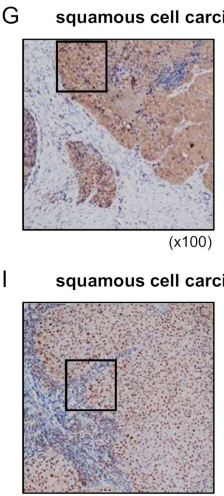
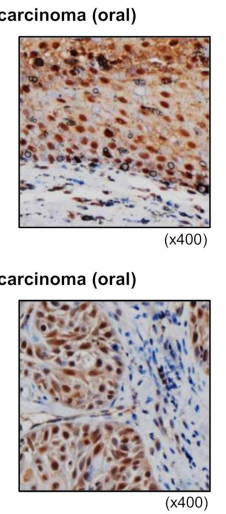

ma (hypopharynx)
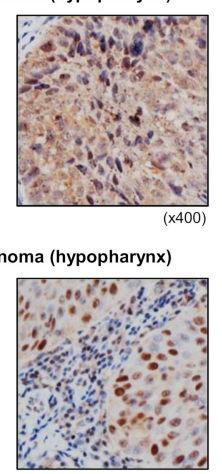

B



D
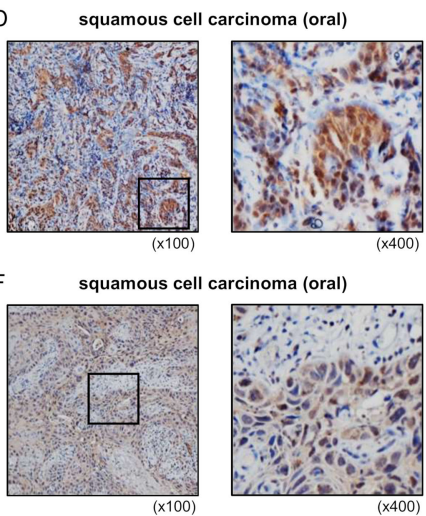

H squamous cell carcinoma (hypopharynx)
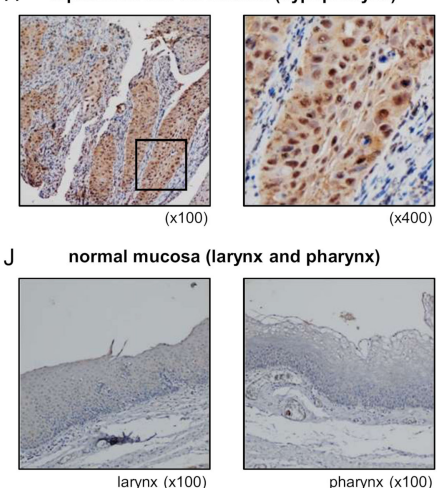



Figure 7. Overexpression of STAMBP in HNSCC clinical specimens. (A-I) Expression of STAMBP was investigated by immunohistochemical staining of HNSCC clinical specimens. Overexpression of STAMBP was detected in the nuclei and/or cytoplasm of cancer cells. (J) Extremely weak expression of STAMBP in normal mucosa of larynx and pharynx. 
Table 3. Clinical features of 9 HNSCC cases used for immunohistochemical staining.

\begin{tabular}{ccccccccc}
\hline & Age & Sex & Location & T & N & M & Stage & Differentiation \\
\hline A & 80 & M & larynx & 3 & $2 \mathrm{c}$ & 0 & IVa & moderate \\
B & 73 & M & larynx & 3 & 0 & 0 & III & poor \\
C & 77 & M & oral & 2 & $2 \mathrm{~b}$ & 0 & Iva & moderate \\
D & 42 & F & oral & $4 \mathrm{a}$ & 0 & 0 & IVa & poor \\
E & 51 & M & oral & 2 & 0 & 0 & II & well \\
F & 52 & F & oral & $4 \mathrm{a}$ & $2 \mathrm{c}$ & 1 & Ivc & well \\
G & 72 & M & hypopharynx & 2 & 0 & 0 & II & moderate \\
H & 64 & M & hypopharynx & 2 & $2 \mathrm{~b}$ & 0 & IVa & well \\
I & 70 & M & hypopharynx & 2 & $2 \mathrm{~b}$ & 0 & Iva & well \\
\hline
\end{tabular}

To confirm our immunostaining results, we analyzed gene expression data of GEO database (accession number: GSE6631). Analysis of gene expression data showed that expression of STAMBP was significantly upregulated in HNSCC clinical specimens (Figure S9).

\section{Discussion}

Owing to the high rate of recurrence and metastasis in HNSCC, HNSCC is still a deadly cancer, with an average 50\% overall 5-year survival rate [1-6]. In order to improve treatment outcomes in patients with HNSCC, it is essential to develop treatments for cases with recurrence and metastasis. Advanced genomic approaches are effective for elucidating the molecular pathogenesis of HNSCC, leading to the identification of molecular targets for treatment.

As part of the unique biological nature of miRNAs, a single miRNA can control (directly or indirectly) many RNA transcripts in each cell. Therefore, the aberrant expression of miRNA influences multiple pathways, including cell proliferation, migration, invasion, and apoptosis. Aberrantly expressed miRNAs disrupt RNA expression networks, resulting in cancer cell initiation, development, metastasis, and drug resistance [11-15]. Accordingly, we have sequentially identified antitumor miRNAs and their controlled molecular targets and pathways in HNSCC cells based on miRNA signatures [16-20]. We recently created an HNSCC miRNA expression signature by RNA sequencing [20]. Notably, our signatures revealed that some miRNA passenger strands, e.g., miR-143-5p, $m i R-145-3 p, m i R-150-3 p, m i R-199 a-3 p$, and $m i R-199 b-3 p$ were downregulated in HNSCC tissues and that their expression status was closely involved in HNSCC molecular pathogenesis [20,23,27]. More recently, our group revealed that passenger strands of miRNAs exert antitumor roles by targeting several oncogenes in prostate cancer, renal cell carcinoma, esophageal squamous cell carcinoma, and lung cancer [28-34]. The participation of passenger strands of miRNAs in carcinogenesis is a new concept in cancer research.

In this study, we revealed that both strands of the miR-99a-duplex (miR-99a-5p and miR-99a-3p) acted as antitumor miRNAs in HNSCC cells. Moreover, we showed that 18 and 30 genes were putative targets of $m i R-99 a-5 p$ and $m i R-99 a-3 p$ regulation, respectively. Many studies have shown that $m i R-99 a-5 p$ acts as an antitumor miRNA in various cancers by targeting many oncogenes [35-39]. In contrast to $m i R-99 a-5 p$, few papers have analyzed the functional significance of $m i R-99 a-3 p$ in cancer cells. Previously, downregulation of $m i R-99 a-3 p$ was detected in castration-resistant prostate cancer (CRPC), and ectopic expression of $m i R-99 a-3 p$ was found to attenuate cancer cell aggressive phenotypes [40]. Moreover, miR-99a-3p was shown to regulate non-SMC condensin I complex subunit G directly, and its overexpression was detected in CRPC clinical specimens, showing a significant association with shorter disease-free survival and advanced clinical stage [40]. In renal cell carcinoma cells, miR-99a-3p significantly inhibits cell proliferation and colony formation through regulating ribonucleotide reductase regulatory subunit-M2 [41]. More recently, lower expression of $m i R-99 a-3 p$ and its mediated molecular pathways were detected in HNSCC by in silico analysis, TCGA database, and Genotype-Tissue Expression sequencing databases [42]. These studies indicated that the downregulation of $m i R-99 a-3 p$ was closely involved in cancer pathogenesis. 
In this study, we aimed to identify oncogenic targets regulated by miR-99a-3p in HNSCC cells. In total, 114 genes were identified as miR-99a-3p-controlled genes, and 10 of these genes (STAMBP, TIMP4, TMEM14C, CANX, SUV420H1, HSP90B1, PDIA3, MTHFD2, BCAT1, and SLC22A15) significantly predicted 5-year overall survival. Notably, among these genes, STAMBP, TIMP4, TMEM14C, CANX, and SUV420H1 were independent prognostic markers of HNSCC, as demonstrated by multivariate analyses. Our preliminary analysis has shown that these genes were controlled by miR-99a-3p in HNSCC cells (Figure S8). Further detailed examinations are necessary in the future. A previous study showed that TIMP4 secretion was regulated by the expression of LOX/SNAI2 axis and contributed to the malignant phenotype of cancers, e.g., thyroid cancer, colon cancer, and breast cancer [43]. Calnexin CANX is an integral protein of the endoplasmic reticulum and acts as a chaperon. In colorectal cancer, overexpression of $C A N X$ predicted poor prognosis of the patients, and its knockdown attenuated aggressive phenotypes of cancer cells [44]. Another study showed that serum levels of CANX were significantly higher in patients with lung cancer, and its expression was a useful sero-diagnostic marker of the patients [45]. Overexpression of SUV420H1 (acts as lysine methyl transferase) enhanced oncogenic ERK signaling through ERK phosphorylation and transcription [46]. These genes may be candidate prognostic markers and therapeutic targets in HNSCC. Functional analysis of these genes will reveal new molecular pathologies for HNSCC.

Among these targets, we further investigated the oncogenic roles of STAMBP in HNSCC cells. STAM-binding protein (STAMBP) is a deubiquitinating enzyme that interacts with the SH3 domain of STAM. This protein plays key roles in cell surface receptor-mediated endocytosis and sorting and in cytokine-mediated signaling for MYC induction and cell cycle progression [47-51]. Whole-exome sequencing revealed that the microcephaly-capillary malformation syndrome was related to recessive mutations in STAMBP [52]. In cancer research, almost no functional analysis of STAMBP has been conducted. A recent study showed that STAMBP expression contributes to melanoma cell migration and invasion through the stabilization of SLUG expression [53]. This result was consistent with our current HNSCC data. In this study, overexpression of STAMBP was detected in HNSCC clinical specimens; knockdown assays using siRNAs demonstrated that migration and invasion were significantly reduced in HNSCC cells. Thus, overexpression of STAMBP may promote cancer cell metastasis. Further studies are needed to analyze the molecular networks controlled by STAMBP in various cancers.

\section{Conclusions}

Based on the miRNA expression signature of HNSCC, we revealed that miR-99a-3p (the passenger strand) acted as an antitumor miRNA in HNSCC cells. In total, 10 genes (STAMBP, TIMP4, TMEM14C, CANX, SUV420H1, HSP90B1, PDIA3, MTHFD2, BCAT1, and SLC22A15) were regulated by miR-99a-3p in HNSCC cells and were closely involved in HNSCC molecular pathogenesis. STAMBP expression was directly controlled by miR-99a-3p, and its overexpression enhanced cancer cell migration and invasion. Our strategy, i.e., identification of antitumor miRNAs and their targets, may be an attractive tool to reveal novel prognostic and therapeutic targets in HNSCC.

Supplementary Materials: The following are available online at http://www.mdpi.com/2073-4409/8/12/1535/s1, Figure S1: Comparison of expression levels of $m i R-99 a-5 p$ and $m i R-99 a-3 p$ in cancer tissues and normal tissues; Figure S2: Spearman's rank tests showing positive correlations between expression levels of $m i R-99 a-5 p$ and miR-99a-3p in TCGA datasets; Figure S3: Photomicrographs of migration and invasion following miRNA or siRNA transfection into HNSCC cells; Figure S4: Incorporation of $m i R-99 a-5 p$ and $m i R-99 a-3 p$ into the RISC in HNSCC cells.; Figure S5: Strategy for identification of $m i R-99 a-5 p$ and $m i R-99 a-3 p$ targets in HNSCC cells; Figure S6: Whole Western blotting images following miRNA or siRNA transfection into HNSCC cells; Figure S7: Nucleotide sequences cloned into luciferase reporter assay vectors; Figure S8: TIMP4, TMEM14C, SUV420H1, and CANX in miR-99a-3p transfected FaDu and SAS cells. miR-99a-3p binding sites in $3^{\prime}$ UTR of each genes are also shown; Figure S9: Significantly increased $(p=0.0060)$ STAMBP expression levels in clinical samples of HNSCC $(\mathrm{N}=22$; GSE6631 dataset); Table S1: Candidate target genes regulated by miR-99a-5p; Table S2: Reagents used in this study. 
Author Contributions: Research planning and paper writing, N.S.; functional analysis of cells, R.O., K.K., Y.Y. and S.M.; clinical data analysis, R.O., K.K. and Y.Y.; gene expression analysis, R.O., Y.Y., S.M., N.K. and T.K.; collection and management of clinical samples, N.K., T.K. and T.H.; data validation, S.M. and T.H.; funding acquisition, N.S., K.K., N.K., T.K. and T.H.

Funding: This research was funded by KAKENHI grants (grant nos. 17K16893, 17K11375, 18K09338, 19K09863, 19K18795, 19K18759).

Conflicts of Interest: The authors declare no conflicts of interest.

\section{References}

1. Siegel, R.L.; Miller, K.D.; Jemal, A. Cancer statistics, 2019. CA Cancer J. Clin. 2019, 69, 7-34. [CrossRef] [PubMed]

2. Leemans, C.R.; Braakhuis, B.J.; Brakenhoff, R.H. The molecular biology of head and neck cancer. Nat. Rev. Cancer 2011, 11, 9-22. [CrossRef] [PubMed]

3. D'Souza, G.; Kreimer, A.R.; Viscidi, R.; Pawlita, M.; Fakhry, C.; Koch, W.M.; Westra, W.H.; Gillison, M.L. Case-control study of human papillomavirus and oropharyngeal cancer. N. Engl. J. Med 2007, 356, 1944-1956. [CrossRef] [PubMed]

4. Seiwert, T.Y.; Zuo, Z.; Keck, M.K.; Khattri, A.; Pedamallu, C.S.; Stricker, T.; Brown, C.; Pugh, T.J.; Stojanov, P.; Cho, J.; et al. Integrative and comparative genomic analysis of HPV-positive and HPV-negative head and neck squamous cell carcinomas. Clin. Cancer Res. 2015, 21, 632-641. [CrossRef] [PubMed]

5. Bonner, J.A.; Harari, P.M.; Giralt, J.; Cohen, R.B.; Jones, C.U.; Sur, R.K.; Raben, D.; Baselga, J.; Spencer, S.A.; Zhu, J.; et al. Radiotherapy plus cetuximab for locoregionally advanced head and neck cancer: 5-year survival data from a phase 3 randomised trial, and relation between cetuximab-induced rash and survival. Lancet Oncol. 2010, 11, 21-28. [CrossRef]

6. Ferris, R.L.; Blumenschein, G., Jr.; Fayette, J.; Guigay, J.; Colevas, A.D.; Licitra, L.; Harrington, K.; Kasper, S.; Vokes, E.E.; Even, C.; et al. Nivolumab for Recurrent Squamous-Cell Carcinoma of the Head and Neck. N. Engl. J. Med. 2016, 375, 1856-1867. [CrossRef]

7. Argiris, A.; Harrington, K.J.; Tahara, M.; Schulten, J.; Chomette, P.; Ferreira Castro, A.; Licitra, L. Evidence-Based Treatment Options in Recurrent and/or Metastatic Squamous Cell Carcinoma of the Head and Neck. Front. Oncol. 2017, 7, 72. [CrossRef]

8. Hsieh, J.C.; Wang, H.M.; Wu, M.H.; Chang, K.P.; Chang, P.H.; Liao, C.T.; Liau, C.T. Review of emerging biomarkers in head and neck squamous cell carcinoma in the era of immunotherapy and targeted therapy. Head Neck 2019, 41, 19-45. [CrossRef]

9. Ha, M.; Kim, V.N. Regulation of microRNA biogenesis. Nat. Rev. Mol. Cell Biol. 2014, 15, 509-524. [CrossRef]

10. Gebert, L.F.R.; MacRae, I.J. Regulation of microRNA function in animals. Nat. Rev. Mol. Cell Biol. 2019, 20, 21-37. [CrossRef]

11. Nohata, N.; Hanazawa, T.; Kinoshita, T.; Okamoto, Y.; Seki, N. MicroRNAs function as tumor suppressors or oncogenes: aberrant expression of microRNAs in head and neck squamous cell carcinoma. Auris Nasus Larynx 2013, 40, 143-149. [CrossRef] [PubMed]

12. Lin, S.; Gregory, R.I. MicroRNA biogenesis pathways in cancer. Nat. Rev. Cancer 2015, 15, 321-333. [CrossRef] [PubMed]

13. Koshizuka, K.; Hanazawa, T.; Arai, T.; Okato, A.; Kikkawa, N.; Seki, N. Involvement of aberrantly expressed microRNAs in the pathogenesis of head and neck squamous cell carcinoma. Cancer Metastasis Rev. 2017, 36, 525-545. [CrossRef] [PubMed]

14. Rupaimoole, R.; Slack, F.J. MicroRNA therapeutics: towards a new era for the management of cancer and other diseases. Nat. Rev. Drug Discov. 2017, 16, 203-222. [CrossRef] [PubMed]

15. Anfossi, S.; Babayan, A.; Pantel, K.; Calin, G.A. Clinical utility of circulating non-coding RNAs-an update. Nat. Rev. Clin. Oncol. 2018, 15, 541-563. [CrossRef] [PubMed]

16. Kikkawa, N.; Hanazawa, T.; Fujimura, L.; Nohata, N.; Suzuki, H.; Chazono, H.; Sakurai, D.; Horiguchi, S.; Okamoto, Y.; Seki, N. miR-489 is a tumour-suppressive miRNA target PTPN11 in hypopharyngeal squamous cell carcinoma (HSCC). Br. J. Cancer 2010, 103, 877-884. [CrossRef] [PubMed] 
17. Nohata, N.; Hanazawa, T.; Kikkawa, N.; Sakurai, D.; Fujimura, L.; Chiyomaru, T.; Kawakami, K.; Yoshino, H.; Enokida, H.; Nakagawa, M.; et al. Tumour suppressive microRNA-874 regulates novel cancer networks in maxillary sinus squamous cell carcinoma. Br. J. Cancer 2011, 105, 833-841. [CrossRef]

18. Fukumoto, I.; Kinoshita, T.; Hanazawa, T.; Kikkawa, N.; Chiyomaru, T.; Enokida, H.; Yamamoto, N.; Goto, Y.; Nishikawa, R.; Nakagawa, M.; et al. Identification of tumour suppressive microRNA-451a in hypopharyngeal squamous cell carcinoma based on microRNA expression signature. Br. J. Cancer 2014, 111, 386-394. [CrossRef]

19. Fukumoto, I.; Hanazawa, T.; Kinoshita, T.; Kikkawa, N.; Koshizuka, K.; Goto, Y.; Nishikawa, R.; Chiyomaru, T.; Enokida, H.; Nakagawa, M.; et al. MicroRNA expression signature of oral squamous cell carcinoma: functional role of microRNA-26a/b in the modulation of novel cancer pathways. Br. J. Cancer 2015, 112, 891-900. [CrossRef]

20. Koshizuka, K.; Nohata, N.; Hanazawa, T.; Kikkawa, N.; Arai, T.; Okato, A.; Fukumoto, I.; Katada, K.; Okamoto, Y.; Seki, N. Deep sequencing-based microRNA expression signatures in head and neck squamous cell carcinoma: Dual strands of pre-miR-150 as antitumor miRNAs. Oncotarget 2017, 8, 30288-30304. [CrossRef]

21. Kinoshita, T.; Nohata, N.; Hanazawa, T.; Kikkawa, N.; Yamamoto, N.; Yoshino, H.; Itesako, T.; Enokida, H.; Nakagawa, M.; Okamoto, Y.; et al. Tumour-suppressive microRNA-29s inhibit cancer cell migration and invasion by targeting laminin-integrin signalling in head and neck squamous cell carcinoma. Br. J. Cancer 2013, 109, 2636-2645. [CrossRef] [PubMed]

22. Koshizuka, K.; Kikkawa, N.; Hanazawa, T.; Yamada, Y.; Okato, A.; Arai, T.; Katada, K.; Okamoto, Y.; Seki, N. Inhibition of integrin beta1-mediated oncogenic signalling by the antitumor microRNA-29 family in head and neck squamous cell carcinoma. Oncotarget 2018, 9, 3663-3676. [CrossRef] [PubMed]

23. Koshizuka, K.; Hanazawa, T.; Kikkawa, N.; Arai, T.; Okato, A.; Kurozumi, A.; Kato, M.; Katada, K.; Okamoto, Y.; Seki, N. Regulation of ITGA3 by the anti-tumor miR-199 family inhibits cancer cell migration and invasion in head and neck cancer. Cancer Sci. 2017, 108, 1681-1692. [CrossRef] [PubMed]

24. Fukumoto, I.; Kikkawa, N.; Matsushita, R.; Kato, M.; Kurozumi, A.; Nishikawa, R.; Goto, Y.; Koshizuka, K.; Hanazawa, T.; Enokida, H.; et al. Tumor-suppressive microRNAs (miR-26a/b, miR-29a/b/c and miR-218) concertedly suppressed metastasis-promoting LOXL2 in head and neck squamous cell carcinoma. J. Hum. Genet. 2016, 61, 109-118. [CrossRef]

25. Chen, D.; Cabay, R.J.; Jin, Y.; Wang, A.; Lu, Y.; Shah-Khan, M.; Zhou, X. MicroRNA Deregulations in Head and Neck Squamous Cell Carcinomas. J. Oral. Maxillofac. Res. 2013, 4, e2. [CrossRef]

26. Chen, Y.T.; Yao, J.N.; Qin, Y.T.; Hu, K.; Wu, F.; Fang, Y.Y. Biological role and clinical value of miR-99a-5p in head and neck squamous cell carcinoma (HNSCC): A bioinformatics-based study. FEBS Open Bio 2018, 8, 1280-1298. [CrossRef]

27. Yamada, Y.; Koshizuka, K.; Hanazawa, T.; Kikkawa, N.; Okato, A.; Idichi, T.; Arai, T.; Sugawara, S.; Katada, K.; Okamoto, Y.; et al. Passenger strand of miR-145-3p acts as a tumor-suppressor by targeting MYO1B in head and neck squamous cell carcinoma. Int. J. Oncol. 2018, 52, 166-178. [CrossRef]

28. Goto, Y.; Kurozumi, A.; Arai, T.; Nohata, N.; Kojima, S.; Okato, A.; Kato, M.; Yamazaki, K.; Ishida, Y.; Naya, Y.; et al. Impact of novel miR-145-3p regulatory networks on survival in patients with castration-resistant prostate cancer. Br. J. Cancer 2017, 117, 409-420. [CrossRef]

29. Misono, S.; Seki, N.; Mizuno, K.; Yamada, Y.; Uchida, A.; Arai, T.; Kumamoto, T.; Sanada, H.; Suetsugu, T.; Inoue, H. Dual strands of the miR-145 duplex (miR-145-5p and miR-145-3p) regulate oncogenes in lung adenocarcinoma pathogenesis. J. Hum. Genet. 2018, 63, 1015-1028. [CrossRef]

30. Misono, S.; Seki, N.; Mizuno, K.; Yamada, Y.; Uchida, A.; Sanada, H.; Moriya, S.; Kikkawa, N.; Kumamoto, T.; Suetsugu, T.; et al. Molecular Pathogenesis of Gene Regulation by the miR-150 Duplex: miR-150-3p Regulates TNS4 in Lung Adenocarcinoma. Cancers 2019, 11. [CrossRef]

31. Yamada, Y.; Arai, T.; Kojima, S.; Sugawara, S.; Kato, M.; Okato, A.; Yamazaki, K.; Naya, Y.; Ichikawa, T.; Seki, N. Regulation of antitumor miR-144-5p targets oncogenes: Direct regulation of syndecan-3 and its clinical significance. Cancer Sci. 2018, 109, 2919-2936. [CrossRef] [PubMed]

32. Uchida, A.; Seki, N.; Mizuno, K.; Misono, S.; Yamada, Y.; Kikkawa, N.; Sanada, H.; Kumamoto, T.; Suetsugu, T.; Inoue, $\mathrm{H}$. Involvement of dual-strand of the miR-144 duplex and their targets in the pathogenesis of lung squamous cell carcinoma. Cancer Sci. 2019, 110, 420-432. [CrossRef] [PubMed] 
33. Sanada, H.; Seki, N.; Mizuno, K.; Misono, S.; Uchida, A.; Yamada, Y.; Moriya, S.; Kikkawa, N.; Machida, K.; Kumamoto, T.; et al. Involvement of Dual Strands of miR-143 (miR-143-5p and miR-143-3p) and Their Target Oncogenes in the Molecular Pathogenesis of Lung Adenocarcinoma. Int. J. Mol. Sci. 2019, 20. [CrossRef] [PubMed]

34. Shimonosono, M.; Idichi, T.; Seki, N.; Yamada, Y.; Arai, T.; Arigami, T.; Sasaki, K.; Omoto, I.; Uchikado, Y.; Kita, Y.; et al. Molecular pathogenesis of esophageal squamous cell carcinoma: Identification of the antitumor effects of miR1453p on gene regulation. Int. J. Oncol. 2019, 54, 673-688. [CrossRef]

35. Shi, Y.; Bo, Z.; Pang, G.; Qu, X.; Bao, W.; Yang, L.; Ma, Y. MiR-99a-5p regulates proliferation, migration and invasion abilities of human oral carcinoma cells by targeting NOX4. Neoplasma 2017, 64, 666-673. [CrossRef]

36. Tsai, T.F.; Lin, J.F.; Chou, K.Y.; Lin, Y.C.; Chen, H.E.; Hwang, T.I. miR-99a-5p acts as tumor suppressor via targeting to $\mathrm{mTOR}$ and enhances RAD001-induced apoptosis in human urinary bladder urothelial carcinoma cells. OncoTargets Ther. 2018, 11, 239-252. [CrossRef]

37. Yin, H.; Ma, J.; Chen, L.; Piao, S.; Zhang, Y.; Zhang, S.; Ma, H.; Li, Y.; Qu, Y.; Wang, X.; et al. MiR-99a Enhances the Radiation Sensitivity of Non-Small Cell Lung Cancer by Targeting mTOR. Cell Physiol. Biochem. 2018, 46, 471-481. [CrossRef]

38. Liu, Y.; Li, B.; Yang, X.; Zhang, C. MiR-99a-5p inhibits bladder cancer cell proliferation by directly targeting mammalian target of rapamycin and predicts patient survival. J. Cell Biochem. 2019, 120, 19330-19337. [CrossRef]

39. Tao, C.; Sun, H.; Sang, W.; Li, S. miRNA-99a inhibits cell invasion and migration in liver cancer by directly targeting HOXA1. Oncol. Lett. 2019, 17, 5108-5114. [CrossRef]

40. Arai, T.; Okato, A.; Yamada, Y.; Sugawara, S.; Kurozumi, A.; Kojima, S.; Yamazaki, K.; Naya, Y.; Ichikawa, T.; Seki, N. Regulation of NCAPG by miR-99a-3p (passenger strand) inhibits cancer cell aggressiveness and is involved in CRPC. Cancer Med. 2018, 7, 1988-2002. [CrossRef]

41. Osako, Y.; Yoshino, H.; Sakaguchi, T.; Sugita, S.; Yonemori, M.; Nakagawa, M.; Enokida, H. Potential tumorsuppressive role of microRNA99a3p in sunitinibresistant renal cell carcinoma cells through the regulation of RRM2. Int. J. Oncol. 2019, 54, 1759-1770. [CrossRef] [PubMed]

42. Wei, G.G.; Guo, W.P.; Tang, Z.Y.; Li, S.H.; Wu, H.Y.; Zhang, L.C. Expression level and prospective mechanism of miRNA-99a-3p in head and neck squamous cell carcinoma based on miRNA-chip and miRNA-sequencing data in 1, 167 cases. Pathol. Res. Pr. 2019, 215, 963-976. [CrossRef] [PubMed]

43. Boufraqech, M.; Zhang, L.; Nilubol, N.; Sadowski, S.M.; Kotian, S.; Quezado, M.; Kebebew, E. Lysyl Oxidase (LOX) Transcriptionally Regulates SNAI2 Expression and TIMP4 Secretion in Human Cancers. Clin. Cancer Res. 2016, 22, 4491-4504. [CrossRef] [PubMed]

44. Ryan, D.; Carberry, S.; Murphy, A.C.; Lindner, A.U.; Fay, J.; Hector, S.; McCawley, N.; Bacon, O.; Concannon, C.G.; Kay, E.W.; et al. Calnexin, an ER stress-induced protein, is a prognostic marker and potential therapeutic target in colorectal cancer. J. Transl. Med. 2016, 14, 196. [CrossRef] [PubMed]

45. Kobayashi, M.; Nagashio, R.; Jiang, S.X.; Saito, K.; Tsuchiya, B.; Ryuge, S.; Katono, K.; Nakashima, H.; Fukuda, E.; Goshima, N.; et al. Calnexin is a novel sero-diagnostic marker for lung cancer. Lung Cancer 2015, 90, 342-345. [CrossRef] [PubMed]

46. Vougiouklakis, T.; Sone, K.; Saloura, V.; Cho, H.S.; Suzuki, T.; Dohmae, N.; Alachkar, H.; Nakamura, Y.; Hamamoto, R. SUV420H1 enhances the phosphorylation and transcription of ERK1 in cancer cells. Oncotarget 2015, 6, 43162-43171. [CrossRef]

47. Li, H.; Seth, A. An RNF11: Smurf2 complex mediates ubiquitination of the AMSH protein. Oncogene 2004, 23, 1801-1808. [CrossRef]

48. McCullough, J.; Clague, M.J.; Urbe, S. AMSH is an endosome-associated ubiquitin isopeptidase. J. Cell Biol. 2004, 166, 487-492. [CrossRef]

49. Agromayor, M.; Martin-Serrano, J. Interaction of AMSH with ESCRT-III and deubiquitination of endosomal cargo. J. Biol. Chem. 2006, 281, 23083-23091. [CrossRef]

50. Ma, Y.M.; Boucrot, E.; Villen, J.; Affar el, B.; Gygi, S.P.; Gottlinger, H.G.; Kirchhausen, T. Targeting of AMSH to endosomes is required for epidermal growth factor receptor degradation. J. Biol. Chem. 2007, 282, 9805-9812. [CrossRef]

51. Meijer, I.M.; van Rotterdam, W.; van Zoelen, E.J.; van Leeuwen, J.E. Recycling of EGFR and ErbB2 is associated with impaired Hrs tyrosine phosphorylation and decreased deubiquitination by AMSH. Cell Signal. 2012, 24, 1981-1988. [CrossRef] [PubMed] 
52. McDonell, L.M.; Mirzaa, G.M.; Alcantara, D.; Schwartzentruber, J.; Carter, M.T.; Lee, L.J.; Clericuzio, C.L.; Graham, J.M., Jr.; Morris-Rosendahl, D.J.; Polster, T.; et al. Mutations in STAMBP, encoding a deubiquitinating enzyme, cause microcephaly-capillary malformation syndrome. Nat. Genet. 2013, 45, 556-562. [CrossRef] [PubMed]

53. Iwakami, Y.; Yokoyama, S.; Watanabe, K.; Hayakawa, Y. STAM-binding protein regulates melanoma metastasis through SLUG stabilization. Biochem. Biophys. Res. Commun. 2018, 507, 484-488. [CrossRef] [PubMed]

(C) 2019 by the authors. Licensee MDPI, Basel, Switzerland. This article is an open access article distributed under the terms and conditions of the Creative Commons Attribution (CC BY) license (http://creativecommons.org/licenses/by/4.0/). 